\title{
Seroprevalence of Hepatitis B, Hepatitis C and Human Immunodeficiency Viruses Amongst Drug Users in Amritsar
}

Dear Editor,

Drug addicts represent a high risk group for acquiring parenterally transmitted viral infections like human immunodeficiency virus (HIV), hepatitis $\mathrm{C}$ virus (HCV) and hepatitis B virus (HBV). It is very likely that an injecting drug user (IDU) infected with HIV will also be infected with HBV and/or HCV because of common high risk behaviours. ${ }^{1}$ Amritsar being border city, is a seat of international drug trafficking and the menace of drug addiction. Hepatitis B virus (HBV) has 300 million carriers worldwide, carrier rate in the general population in India is 2-3\% with an estimated 43 million carriers and antibodies against hepatitis $\mathrm{C}$ virus (HCV) are present in approximately 15 million with prevalence rate of $2 \%{ }^{2}$ There are 5.134 million HIV infected cases in India. HIV, HCV and HBV infections may promote each other and be related to needle sharing behaviour in drug users and to different other living habits. ${ }^{3}$

The study carried out in Department of Microbiology, Government medical college, Amritsar, included 250 drug users (both I/V and oral) attending drug de-addiction center and 100 healthy individual with no history of drug use, as control group.

After pretest counselling and informed consent blood sample (5 mL) was collected observing universal precautions. HIV, HBV and HCV infections were detected by ELISA using commercially available kits and following manufacturer's instructions. HIV positive samples were subjected to two other ELISA/rapid/simple (E/R/S) tests. HCV antibodies positive samples were sent to Maulana Azad medical college, New Delhi, for HCV RNA detection by PCR. Seroprevalance of HBs $\mathrm{Ag}, \mathrm{HCV}$ and anti HIV and co-infections, among various groups is given in the table.

Nine out of $30(33 \%) \mathrm{HCV}$ positive sera were also positive for HCV RNA. There was increased prevalence of HBsAg in oral group, (84.75\%), overall carrier rate of HBsAg being 23.6\%. This finding is consistent with an earlier study. ${ }^{4}$ Seroprevalance of anti HCV in the present study is $14.8 \%$. Intravenous drug addiction is a major source of infection with hepatitis $\mathrm{C}$ virus. ${ }^{5}$ Seroprevalance of $9.6 \%$ of HIV antibodies is much lower than the study from Delhi. ${ }^{1}$ Non-injectable drug users (NIDUs) are less stigmatized than IDU, although NIDUs are more likely to have sexual relationship. NIDUs infected with $\mathrm{HIV}$ and/or HCV may thereby function as a sexual bridge of infection to uninfected lower risk population. PCR study showed $33.3 \%$ positivity for HCV RNA which indicates that most anti HCV positive cases are chronic in nature.

Such studies will establish early diagnosis and help in initiating treatment which may present long term sequelae like chronic active hepatitis, cirrhosis and hepatocellular

Table: Seroprevalence of HIV, HCV and HBV in various groups of drug addicts and controls

\begin{tabular}{lcccc}
\hline Route of drug intake & HBsAg & Anti HCV & Anti HIV & Co-infections \\
\hline Intravenous 18 (7.2) & $9(15.25)$ & $13(35.13)$ & $4(16.67)$ & HBsAg + HCV13 (5.2) \\
Oral 193 (77.2) & $34(57.63)$ & $10(27.02)$ & $14(58.33)$ & HBsAg + HIV 2 (0.8) \\
Intravenous + Oral 39 (15.6) & $16(27.12)$ & $14(37.85)$ & $6(25.00)$ & HIV + HCV 7 (2.8) \\
Control Group No Drug Intake 100 & $2(2)$ & Nil & Nil & HCV + HBsAg + HIV2 (0.8) \\
\hline
\end{tabular}

$P$ value significant in drug users by every route. Numbers in parenthesis represent percentage 
carcinoma. Education, counselling and behaviour modifications are the corner stones in prevention of parenterally transmitted viral infections.

\section{References}

1. Baveja UK, Chattopadhye D, Khera R, Joshi PL. A cross sectional serological study of the coinfection of hepatitis B virus, hepatitis $\mathrm{C}$ virus and human immunodeficiency virus amongst a cohort of IDUs at Delhi. Indian J Med Microbiol 2003;21;280-3.

2. Tandon BN. Hepatitis B and C: A holistic approach. Gasteroenterol Today 2002;6:168-9.

3. Baozhang T, Kaining Z, Jinxing K, Ruchang X, Ming L, Caixi $\mathrm{Z}$, et al. Infection with human immunodeficiency virus and hepatitis virus in Chinese drug addicts. Epidemiol Infect 1997;119:343-7.
4. Panda S, Chatterjee A, Bhattacharjee S, Ray B, Saha MK, Bhattacharya SK. HIV, Hepatitis B, Sexual practice in the street recruited injected drug users of Calcutta: risk perception versus observed risks. Int J STD AIDS 1998;9:214-8.

5. Sendi P, Hoffman M, Bucher HC, Erb P, Haller P, Gyr N, et al. Intravenous opiate maintenance in a cohort of injecting drug addicts. Drug Alcohol Depend 2003;69:183-8.

*R Tiwari, A Aggarwal, P Devi

Department of Microbiology, Government Medical College, Amritsar - 143 001, Punjab, India

*Corresponding author(email: <tiwari_doc@ @ediffmail.com>)

Received : 29-09-05

Accepted : 12-02-06 